INTEGRATING MULTI-CRITERIA MODELS AND GEOGRAPHICAL INFORMATION SYSTEM FOR CEMETERY SITE SELECTION (A CASE STUDY OF THE SANANDAJ CITY, IRAN)

POVEZOVANJE VEČKRITERIJSKIH MODELOV IN GEOGRAFSKEGA INFORMACIJSKEGA SISTEMA (GIS) ZA ISKANJE USTREZNE LOKACIJE ZA GRADNJO POKOPALISCA (ŠTUDIJA PRIMERA: SANANDAJ, IRAN)

Sedigheh Lotfi, Kiumars Habibi, Mohammad Javad Koohsari

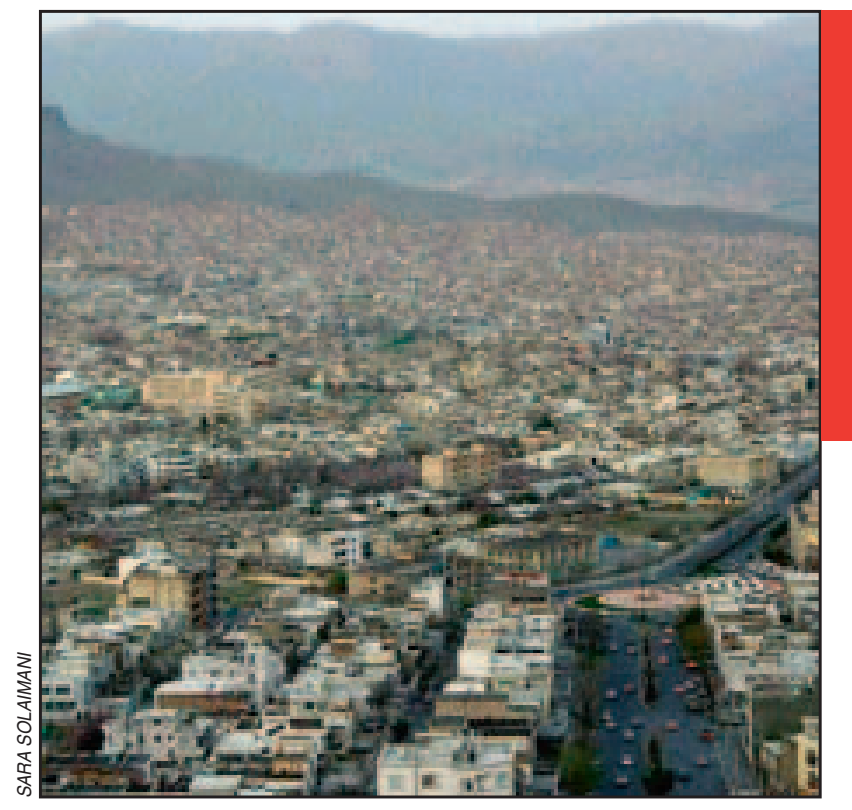

Sanandaj is a rather new city in Iran, exceptional for its Sunni Islam population. Sandandaj je razmeroma mlado mesto, ki je v Iranu izjema zaradi prevlade sunitskih muslimanov. 


\title{
Integrating multi-criteria models and Geographical information system for cemetery site selection (a case study of the Sanandaj city, Iran)
}

\author{
DOI: $10.3986 /$ AGS49106 \\ UDC: $913: 711.14(55)$ \\ 711.14:718(55) \\ COBISS: 1.01
}

\begin{abstract}
The ever increasing urban population growth has created many implications in land use planning in the most of developing countries. Traditional methods of spatial planning are still useful, but they need to be upgraded according to new methodological, technological possibilities and full complexity of spatial planning. The factors which influence the urban structure and its socio-economic life are countless, and so to deal with a huge set of data, Geographic information system (GIS) techniques can help to organize and control the impact of different problems. Urban utilities are the vital elements to provide comfort and amenity for the residents. Clearly in many cases the inappropriate sitting of urban infrastructures has decreased the efficiency and sustainability of the cities. Today GIS as powerful processing means can provide different alternatives for land use planning. One of the most socio-religious urban land uses in Iran is cemetery. Traditionally cemeteries are located in the vicinity of a holy shrine or specified by the local authorities. However, these sites are suitable by the view of people and religious groups but they impose many physical problems such as poor health conditions or accessibility due to the rapid expansion of the city by the population increase. This paper attempts to select a right site for a new cemetery in town Sanandaj, as the old one now has no empty space. The paper applies GIS and Analytic hierarchy process (AHP) techniques to find an appropriate area. The results show that the integrated GIS and AHP model has a high potential to compare different alternatives by investigating multi-criteria models and different factors which are involved in an urban utility site selection.
\end{abstract}

KEY WORDS: geography, urban land use, Multi-criteria model, cemetery site selection, GIS, Iran

The article was submitted for publication on February 2, 2008.

\section{ADDRESSES:}

Sedigheh Lotfi, Ph. D.

Department of Urban Planning, University of Mazandaran

Pasdaran Street, 47415, P. O. Box: 416, Babolsar, Iran

E-mail: sedlotfi@yahoo.com

\section{Kiumars Habibi, Ph. D.}

Department of Urban Planning, University of Kurdistan, P. O. Box 416

Sanandaj, Iran

E-mail: habibi_ki@yahoo.co.uk

\section{Mohammad Javad Koohsari, M.Sc.}

Department of Urban and Regional Planning, Faculty of Fine Arts, University of Tehran

16 Azar Street, Enghelab Avenue, Tehran, Iran

E-mail: kouhsaary@yahoo.com

\section{Contents}

1 Introduction 181

$2 \quad$ Material and methods 181

3 The introduction and application of the model 184

4 Results and Discussion 188

5 References 189 


\section{Introduction}

The increasing level of urbanization has created many constrains for urban authorities and planners. Today one of the major challenges is how to distribute urban utilities with regard to the various land uses and population density. Obviously to manage and make decisions is not as easy as has been before the new pace of urban growth in the most of the developing world. One of the valuable breakthroughs in the field of urban planning is the application of the GIS. Geographical information system with its multi capacity to integrate; analysis of huge data and information is a powerful tool to understand the behavior of human settlements. The economic boom of 1970 due to oil export has changed the features of many Iranian cities such as Sanandaj. The city is one of the important centers of population concentration in the west of Iran which ought its present form to urban development plans such as master and detailed. The master plan was designed in response to the population growth and their needs to urban infrastructures. This plan was provided by Majan Consulting Engineers in 1976 (Housing and Town Planning Center of Kurdistan Province 1976).

However the plan imposed a different spatial structure and transformed the old traditional fabric of the city, it became a cause of further physical expansion of the city.

Rural-urban migration was primarily a consequence of agricultural decline due to injection of oil revenues to the Iranian economy which undermined rural economy. Moreover invasion of Iraqi troops to Iran has pushed much population from the border contact zones toward the city as the number of population increased from 95,000 in 1976 to 205,000 in 1986 and 315,000 in 2006. The most obvious impact of such events was the extensive growth of the city (Housing and Town Planning Center of Kurdistan Province 2000).

This Study is based on two assumptions: firstly the present cemetery is not suitable and created many socio-economic and environmental problems, and secondly an appropriate site selection of urban land use is difficult and costly without applying GIS because many indicators and criteria influence the process of sitting which must be considered and weighted in a logical framework.

The capability of GIS as a set of soft and hardware has proved to be suitable world-wide to site selection for urban utilities as Al-Jarreh and Abu-Qdais (2004) addressed the problem of sitting a new landfill using an intelligent system based on fuzzy inference. They considered several factors in the sitting process including topography and geology, natural resources, socio-cultural aspects, and economy and safety. A weighting system was used for all of the considered factors. The results from testing the system using different sites show the effectiveness of the system in the selection process. Partovi (2006) presented a strategic solution to the facility location problem which incorporates both external and internal criteria in the decision-making process by using AHP with Analytic Network Process (ANP) and Quality Function deployment (QFD). Chang et al. (2008) used multi-criteria and fuzzy model with the help of GIS to find a site for the southern Texas waste disposal, they followed the procedure in two stages. Rashed (2003) assessed the vulnerability of earthquake hazards through spatial analysis of urban areas in Bangladesh; he classified three area of high, medium and low risk by integrating fuzzy logic and AHP. The multi-criteria method which include a collection of techniques (the sum of weightings and conversion analyses) allows some of criteria depended to a given subject to be evaluated and weighted. Then they can be ranked by the expertise and planners (Higges 2006). The multi-criteria methods have potential to decrease the cost and time by increasing the resolution in spatial decisions which can provide an appropriate framework for spatial dimensions of the town planning. Salvory et al. (2005) in a study by integrating GIS and multi-criteria methods investigated the ecological suitability for different land uses such as residential, industrial, forest and natural conservation. They suggested an appropriate layer for each use and finally the most suitable uses for each of them were recommended. Sung et al. (2005) used AHP model to sitting for rail station. They applied fuzzy logic and sensitive analysis for weighting of different criteria.

Today, the land use management of urban infrastructure is the main challenge of most of the urban authorities and planners. The main aim of this study is to find a place for the new cemetery in Sanandaj which has the least negative socio-economic environmental impact. Sanandaj city is the political center of Kurdistan province in the western border of Iran.

\section{Material and methods}

Sanandaj is a fast-growing political and economical center of Kurdistan province in the western border of Iran. Two main factors accelerating the expansion of the city are a relative high natural population growth 


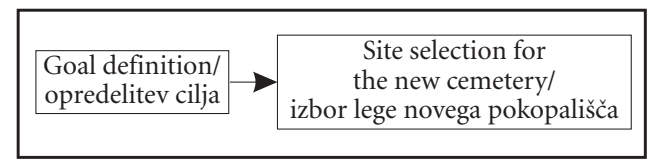

and the second rural-urban migration, as the number of population increased from 95,000 in 1976 to more than 300,000 in 2006 (SCI 2007). The most obvious resultant of such events was the extensive growth of the city fabric. Many of the urban utilities of the city can not meet the increasing needs of its population. One of such utilities is city's cemetery which now has no empty place for the new demand. Finding an appropriate new place is the main aim of this research by using new techniques. The research has followed the path of a conceptual flow as illustrated here.

One of the main capability of GIS as an exclusive system is its potential of integration, modeling, and site selecting through land valuation. By integrating and compositing the different criteria the most appropriated location can be selected. There are different methods for criteria composition which some of them include as follow:

Boolean Logic: this logic originated from the name of an English mathematician Gorge Boolean who by valuating each unit in information layer on the base zero and one value. The logical composite of values is in two ways; yes or no, each place examined by valuating as true or false and there is no other option. In the end the model introduces a location which is appropriated or inappropriate for a given activity. The main shortcomings of the model are: it can not be applied to the real world because the results of the model are $100 \%$ true or false; if a criterion becomes inappropriate in the process of sitting, that location will be omitted; Also when the criteria are many, the model has no capability to find an appropriate location for sitting.

Index Overlay: the different factors and classes has different values in this model and then a set of flexible maps will be provide which has a range of numbers. For example, gradient has different degrees for different purposes which may change from 2 to $5^{\circ}$. Here, an appropriate gradient for urban development is between 3 to $8 \%$. The process of weighting will be done for fault line, gradient direction, soil and etc. Then by two variable analyses the layers composite and each location with higher values would be selected.

Probability Logic: in this model by using coincident coefficient model, Kappa indicator, entropy, Moran indicator and Cramer the different information layers would be integrated and then analyzed in two or multi layers.

Coefficient correlation: two layers are analyzed on the base of their statistical correlation. For instance the relationship between height and temperature, disease distribution and population density. The aim is to find the degree of association and weigh the layers is on the base of their correlation coefficient.

Fuzzy logic or the logic of black and uncertainty: fuzzy logic was first developed by. Lotfi A. Zadeh an Iranian-American scholar in the 1960s in order to provide mathematical rules and functions which permitted natural language queries. Fuzzy logic provides a means of calculating. It enabled many concepts, variables and systems to be illustrated mathematically and provided a background for reasoning, control and decision making in the uncertain conditions. The reason to use fuzzy model is that a fuzzy set unlike the Boolean has the capability to enter the factors in a consistent rang (Zadeh 1975).

The AHP approach, developed by Saaty (1980), is one of the more extensively used multi-criteria decision making MCDM methods. The AHP has been applied to a wide variety of decisions and the human judgment process (Lee et al. 2001). The approach is used to construct an evaluation model and has criterion weights. It integrates different measures into a single overall score for ranking decision alternatives. Applying it usually results in simplifying a multiple criterion problem by decomposing it into a multilevel hierarchical structure. Obtaining solutions in the AHP is not a statistical procedure, because it can help either a single decision maker or a decision group to solve a MCDM problem. Applying the AHP procedure involves three basic steps: decomposition, or the hierarchy construction; comparative judgments, or defining and executing data collection to obtain pair wise comparison data on elements of the hierarchical structure; and synthesis of priorities, or constructing an overall priority rating (Harker and Vargas 1987).

In first stage of application of AHP model, the decision makers need to break down complex multiple criteria decision problems into its component parts of which every possible attributes are arranged into multiple hierarchical levels.

The criteria and sub-criteria are not each equally important to the decision at each level of the hierarchy, and each alternative rates differently on each criteria. AHP can provide an analytical process that 
is able to combine and consolidate the evaluations of the alternatives and criteria by either an individual or group involved in the decision-making task (Crouch and Ritchie 2005).

One notes that two elements being compared at a given time greatly reduces the conceptual complexity of an analysis. This simplification involves assumptions that Saaty (1980) and others (Muralidhar et al. 1990; Partovi 1992) considered reasonable. Given a pairwise comparison, the analysis involves three tasks: (1) developing a comparison matrix at each level of the hierarchy starting from the second level and working down, (2) computing the relative weights for each element of the hierarchy, and (3) estimating the consistency ratio to check the consistency of the judgment. (Chen 2006) the comparisons can be carried out through personal or subjective judgments (Ho 2008).

The 9-point scale used in typical analytic hierarchy studies is ranging from 1 (indifference or equal importance) to 9 (extreme preference or absolute importance) (Table 1). This pairwise comparison enabled the decision maker to evaluate the contribution of each factor to the objective independently, thereby simplifying the decision making process.

Table 1: 9-point intensity of relative importance scale (Saaty and Kearns 1985).

\begin{tabular}{lll}
\hline Intensity of importance & Definition & Explanation \\
\hline 1 & Equal importance & Two activities contribute equally to the objective \\
\hline 5 & Weak importance of one over another & Experience and judgment slightly favor one activity over another \\
\hline 7 & Essential or strong importance & Experience and judgment strongly favor one activity over another \\
\hline 9 & Demonstrated importance & $\begin{array}{l}\text { An activity is strongly favored and its dominance is demonstrated } \\
\text { in practice }\end{array}$ \\
\hline $2,4,6,8$ & Absolute importance & $\begin{array}{l}\text { The evidence favoring one activity over another is of the highest } \\
\text { possible order of affirmation }\end{array}$ \\
\hline
\end{tabular}

Elements in each level are compared in pairs with respect to their importance to an element in the next higher level. Starting at the top of the hierarchy and working down, the pairwise comparisons at a given level can be reduced to a number of square matrices $A=\left[\alpha_{i j}\right]_{n x n}$ as in the following:

$$
\left(\begin{array}{cccc}
a_{11} & a_{12} & \ldots & a_{1 n} \\
a_{21} & a_{22} & \ldots & a_{2 n} \\
\cdot & \cdot & & \cdot \\
a_{1 n} & a_{2 n} & \ldots & a_{n n}
\end{array}\right)
$$

The matrix has reciprocal properties, which are:

$$
a_{j i}=\frac{1}{a_{i j}}
$$

After all pairwise comparison matrices are formed, the vector of weights, $w=\left[w_{1}, w_{2}, \ldots, w_{n}\right]$, is computed on the basis of Saaty's eigenvector procedure. The computation of the weights involves two steps. First, the pairwise comparison matrix $A=\left[\alpha_{i j}\right]_{n x n}$ is normalized by equation (1), and then the weights are computed by equation (2).

$$
a_{i j}{ }^{*}=\frac{a_{i j}}{\sum_{i=1}^{n} a_{i j}}
$$

for all $j=1,2, \ldots, n$

$$
w_{i}=\frac{\sum_{j=1}^{n} a_{i j}{ }^{*}}{n}
$$

for all $i=1,2, \ldots, n$ 
Saaty (1980) showed that there is a relationship between the vector weights, $w$, and the pairwise comparison matrix, $A$, as shown in equation (3).

$$
A w=\lambda_{\max } w
$$

The $\lambda_{\max }$ value is an important validating parameter in AHP and is used as a reference index to screen information by calculating the consistency ratio (CR) of the estimated vector. To calculate the CR, the consistency index (CI) for each matrix of order $n$ can be obtained from equation (4).

$$
C I=\frac{\lambda_{\max }-n}{n-1}
$$

Then, CR can be calculated using equation (5):

$$
C R=\frac{C I}{R I}
$$

Where $R I$ is the random consistency index obtained from a randomly generated pairwise comparison matrix. Table 2 shows the value of the RI from matrices of order 1 to 10 as suggested by Satty (1980). If $C R<0.1$, then the comparisons are acceptable. If, however, $C R \geq 0.1$, then the values of the ratio are indicative of inconsistent judgments. In such cases, one should reconsider and revise the original values in the pairwise comparison matrix A.

Table 2: Random inconsistency indices (ri) for $\mathrm{n}=1-10$ (Saaty 1980).

\begin{tabular}{ccccccccccc}
\hline 10 & 9 & 8 & 7 & 6 & 5 & 4 & 3 & 2 & 1 & $\mathrm{~N}$ \\
\hline 1.49 & 1.46 & 1.41 & 1.32 & 1.24 & 1.12 & 0.9 & 0.58 & 0.00 & 0.00 & $\mathrm{Rl}$ \\
\hline
\end{tabular}

The AHP was adopted in education, engineering, government, industry, management, manufacturing, personal, political, social, and sports (Vaidya and Kumar 2006). The wide applicability is due to its simplicity, ease of use, and great flexibility. It can be integrated with other techniques, for instance, mathematical programming in order to consider not only both qualitative and quantitative factors, but also some real-world resource limitations.

\section{The introduction and application of the model}

There are sets of factors that are important to site selection of a cemetery which includes both spatial-physical factors. The spatial-physical factors usually are the factors which determine the cemetery limits and the physical characteristics of the site (Khodadadi 2003). These factors include:

- Distance from the city: from the religious point of view (Islam) the maximum distance of a cemetery to the city should not exceed the standard $(15 \mathrm{~km})$ which leads to the delay of pray and break of the Moslem fast (Saeednia 2002). Moreover, the distance between city and the cemetery should consider the sanitation issues.

- The physical expansion of the city: cemetery must locate in a direction which there is the least possibility of city expansion.

- The adjacent uses: the site of cemetery needs open spaces covered by trees or barren lands which provide a good limit for the cemetery.

- The dominant wind direction: the direction of the wind must be toward the cemetery and in the case of reverse situation the site should be bounded by tall trees.

- Accessibility: in the Moslem belief Friday is the most sacred day and people prefer to go cemetery to respect their dead relatives. Obviously the appropriate and safe roads are very important.

- Soil type and compositions: Soil type and compositions should not create delay in body decomposition.

- Soil resistance: the ground layers should have resistance against sliding and falling (It means the new excavation should not led to sliding or falling of the old graves).

- The gradient: The gradient of the site has to provide a good and rapid runoff discharges.

- The underground water table: The underground water table should stand at least 5 meter from the grave bed according to article number 40 and 45 of the Environment Organization of Iran. The environmental 
regulations of cemetery site selection have been studied by the EOI comprehensive researches in the country (EOI 1997).

- The surface water: the cemetery should not be sited in the vicinity of rivers, springs or Qanats.

The model was practiced in two stages. In the first stage by applying the Index Overlaying logic in GIS, sites were determined according to the spatial suitability. The different factors were weighted and several flexible maps were produced which include a range of figures. The following criteria were evaluated with respect to their importance:

The dominant wind direction: in this research the areas which were located in the opposite way of the wind weighed as the most appropriated site. The direction of physical expansion of the city: the best areas were the sites which are placed in the opposite direction of the city's growth. The distance of the city: in this model we assumed the sites which have more than $3 \mathrm{~km}(\max 15 \mathrm{~km})$ from the legal limit of the city are the best site for cemetery sitting. The position of surface water: here we considered those areas with more distance from water resource like river are more appropriate for the sitting of the cemetery. Finally the accessibility factor explained by the assumption that the site should has good access to the main transport networks. Each of the above criteria were classified and weighed. These weights are illustrated in figures 3 to 7 .

Table 3: Weighting the dominant wind direction.

\begin{tabular}{lc}
\hline The dominant wind direction & weight \\
\hline The areas which located in the direction of the physical expansion of the city & 0,00 \\
Other areas & 1,00 \\
\hline
\end{tabular}

Table 4: Weighting the direction of physical expansion of the city.

\begin{tabular}{lc}
\hline The direction of physical expansion of the city & weight \\
\hline The areas which located in the direction of the physical expansion of the city & 0,00 \\
Other areas & 1,00 \\
\hline
\end{tabular}

Table 5: Weighting the distance of city.

\begin{tabular}{lc}
\hline distance from the city $(\mathrm{km})$ & weight \\
\hline $0-3$ & 0.00 \\
$3-6$ & 0.50 \\
$6-9$ & 1.00 \\
$9-12$ & 0.75 \\
$12-15$ & 0.25 \\
$<15$ & 0.00 \\
\hline
\end{tabular}

Table 6: Weighting the distance to surface waters.

\begin{tabular}{lc}
\hline distance from the surface waters $(\mathrm{km})$ & weight \\
\hline $0-1$ & 0.00 \\
$1-3$ & 0.25 \\
$3-5$ & 0.50 \\
$5-7$ & 0.75 \\
$<7$ & 1.00 \\
\hline
\end{tabular}

Table 7: Weighting the accessibility factor.

\begin{tabular}{lc}
\hline distance from the main roads $(\mathrm{km})$ & weight \\
\hline$>2$ & 0.00 \\
$1.5-2$ & 0.25 \\
$1-1.5$ & 0.50 \\
$0.5-1$ & 0.75 \\
$0-0.5$ & 1.00 \\
\hline
\end{tabular}




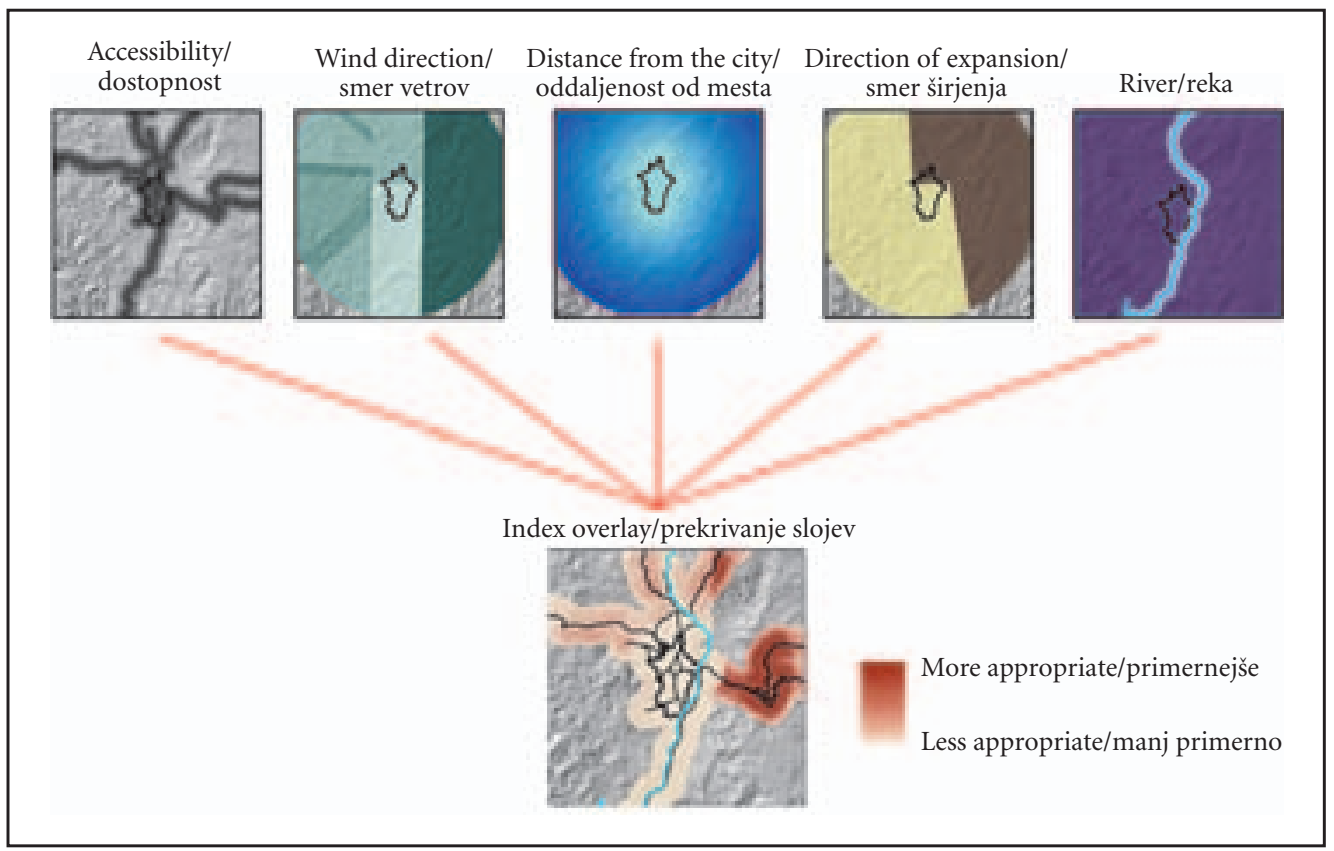

Figure 2: Integrating different criteria by Index Overlay.

The weighted layers were integrated by using overlay functions in GIS, and then the suitability of the sites for cemetery was illustrated with regard of location criteria (Figure 2). The main base map was a digitized township map of Sanandaj which was provided by the Surveying Organization of Iran in 2004 (SOI 2004).

In the second stage by using AHP model for selecting the best area according to the spatial and location, the most important criteria were chosen. Soil type; in this research the soils which are less water absorbent and more penetrable were appropriate for the cemetery as has better capability for body decomposition. The gradient; this factor should be in a degree that lead to a rapid discharge of runoff water. These criteria with other location factors which were weighted in the first stage were analyzed by AHP.

To applying AHP the pair wise comparison matrix of above criteria were showed as follow (Table 4). These pair wise comparison was based by several meeting with local urban authorities and the municipal experts. They have been reviewed many times to coordinate with local conditions and finally the following results were confirmed by the city authorities.

Table 4: The pair wise comparison matrix in AHP model.

\begin{tabular}{lccc}
\hline criteria & location factors & soil type & gradient \\
\hline factors & 1,00 & 2,00 & 3,00 \\
soil type & 0,50 & 1,00 & 2,00 \\
gradient & 0,33 & 0,50 & 1,00 \\
\hline
\end{tabular}

The inconsistency ratio of this comparison obtained the figure of 0.01 , which was acceptable as this should be lesser or equal 0.1. In this study Expert Choice software was used to calculate the relative importance of factors and indicators (Table 5).

Expert Choice software is based on the AHP. At the first, the user must define the problem and enter all the relevant issues into the hierarchy. The decision maker then provides judgments on the elements in the hierarchy in pairs as to their relative importance. After the decision maker sorts the elements into hierarchy levels clustered into similar or homogeneous entities, Expert Choice asks the user how much 
more important, or preferred, $\mathrm{X}$ is compared to $\mathrm{Y}$ with respect to some property. A judgment is made using the AHP verbal or graphical scale or the equivalent 1 to 9 numerical scale. Expert Choice determines if the comparisons are logical and consistent and if not assists the user to improve consistency through its »inconsistency measure«. Finally, all the separate pairwise comparisons are synthesized to calculation of the relative importance of factors.

Table 5: The criteria weighting in AHP model

\begin{tabular}{ll}
\hline criteria & weight \\
\hline location factors & 0.540 \\
soil type & 0.297 \\
gradient & 0.163 \\
\hline
\end{tabular}

The information layers for each criterion was provided through analytical GIS and then by classifying them, the advantages of each class for the cemetery sitting were determined. Following the process these layers were weighted on the base of AHP by the help of Extension added to ArcGIS9 for site selection.

Among the different alternatives two sites obtained more weights. Clearly each model has its shortcomings and is capable only to reveal some limited aspects of the comprehensive nature of environment, so the models are as guide and should be completed by other tools like field study. In this research we used the digital soil type and slope map of Sanandaj which was provided by the SOI (2004).

For the feasibility of the study the two highest weighted sites were examined in respect to their ownership. It necessary to mention that vagueness in urban land ownership is one of the most important factors that prevent the implementation of urban projects in Iran (Hojati 2007); the experiences show that many urban plans ignored the importance of such issue which it leads to the worthless drafts in the municipal document shelves. In this study land price and its ownership were considered for prioritization of the recommended sites (Figure 3). Therefore, the decision makers have more flexibility and local authorities are able to implement city plans.

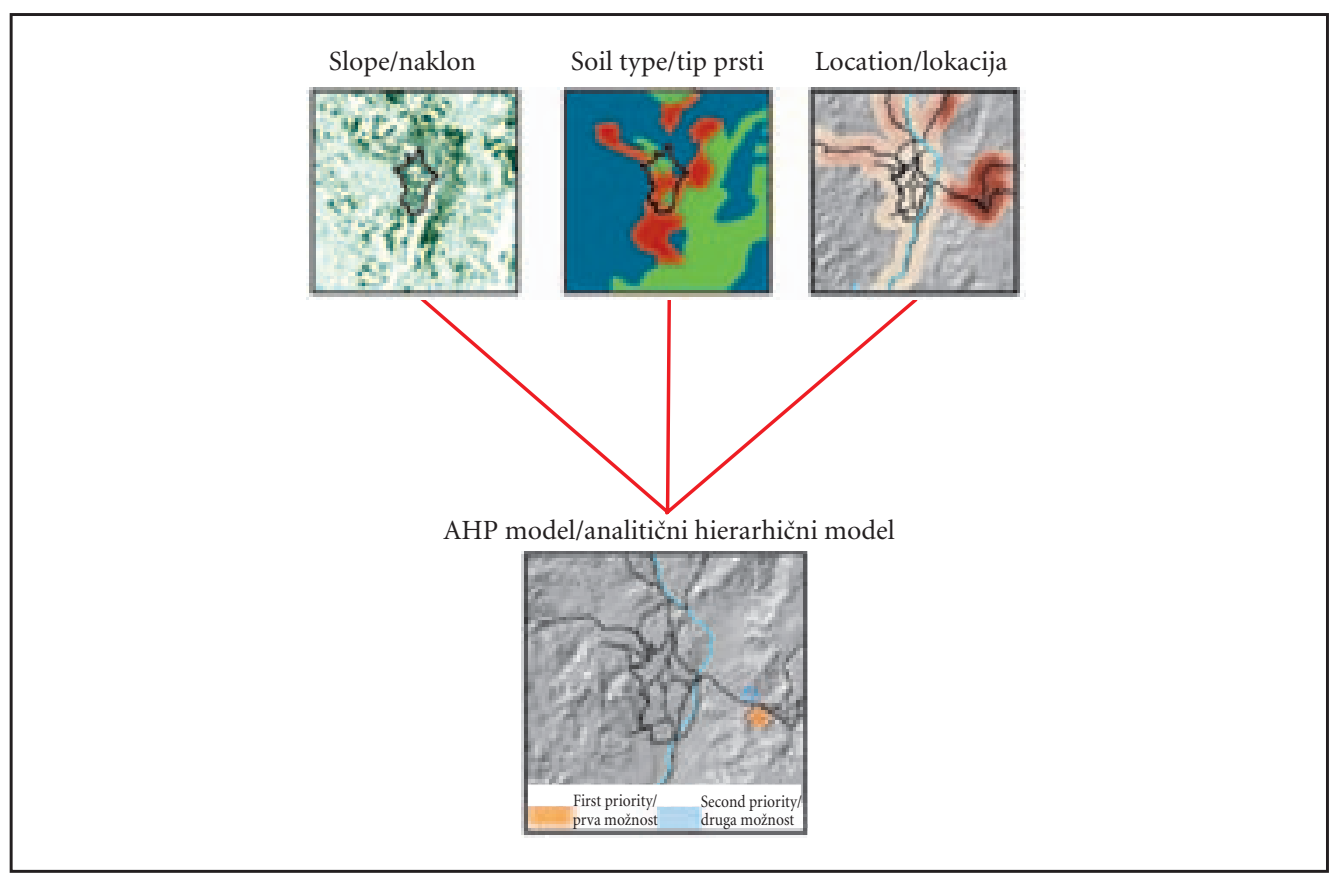

Figure 3: Integrating different criteria by AHP model. 


\section{Results and Discussion}

There are many factors which influence the sitting of urban utilities such as cemetery which the comprehensive analysis of these huge data and information is impossible by using of the traditional methods. The use of traditional method created many problems in urban planning of the country and imposed a high cost on the natural resources. So by applying a capable analytical tool like GIS can ease the process of planning and decrease problems. However we should consider that GIS is still just a tool. GIS users select the input data, they contribute their evaluations and weights and if these inputs are not correct, the results can be very misleading.

The applications of multi-criteria models such as AHP integrated to GIS in urban land use planning is quite efficient and provide the possibility of comparisons of different alternatives to approach the best option.

The recommended model has the potential to be used in other parts of the country with similar conditions or can be reviewed for a specific area by adding other criteria without any change to the generality of the model.

By applying of the urban authority's views, their preferences and considerations will enter to a scientific and goal-oriented approach. Above all, no plan can be implemented without the help of people and the local government. We strongly believe that translation of the model advantages to the all involved bodies in urban planning and management can make the situation more acceptable. The results from the study of present and proposed cemetery can be depicted as follow:

- The wind direction of 5 recent year shows that the dominant winds come from the south region along the river Gheshlaq towards the city. So the proposed cemetery is located opposite the wind direction.

- The distance from the surface water is less than 100 meter in some areas. Moreover the present site is located 500 meter from the main river and tens of semi-depth wells which are the main source of irrigation for agricultural lands. While the average depth of the groundwater is 114, 108, and 127 meter in the neighboring provinces like Ilam, Zanjan and Kermanshah respectively. This figure decreases to 25 meter in the area. Also the normal average depth of underground water is about 68.9 meter in the country. Therefore the underground water contamination is a serious problem in the city. The proposed sites for the future cemetery has a suitable gradient which allow the natural runoff of polluted water and also are located in an appropriate distance from the surface water.

- The gradient of area in the most of the parts is more than $40^{\circ}$ (the standard gradient is below $40^{\circ}$ ). The new sites have an average gradient less than $14-17^{\circ}$.

- The trend of physical growth of the Sanandaj shows more than $90 \%$ of the growth has been towards the south and southeast. So, the present site now is situated in the service zone of the municipality. The research recommended two priorities as illustrated in figure 3. (It meant that this growth related to the housing construction and the attached streets).

- The average mortality rate has been 8 in 1000 population between 1996 and 2006, in other words 2200 persons die each year and each body needs $6 \mathrm{~m}^{2}$ of area which the city needs $13200 \mathrm{~m}^{2}$ or 1.3 hectare of land. From economical point of view the site should be sufficient for the cemetery should cover at least 30 years, and it means the city needs 40 hectare of land. While the present location has a limited extension and roughly sufficient for only 9 years. The proposed sites with 25 hectare which extracted from the application of the model have the potential to cover the future needs of the city and the site has no development limitation for future development.

- The findings of the research are significant for local community and decision makers as the model used here, is generalized and applied to the socio-economic and natural characteristics of the region. In other words the technique has been localized and the new sites were prioritized. It needs to be mentioned that a few study have been done in the country in the field of site selection but as almost all of them concentrated only on a few factors, the results never practiced by the urban authorities. The present research ends with following conclusion. The study revealed selecting a new site for the near future to locate the new cemetery is quite crucial. So this study tried to investigate many socio-economic and physical criteria by using GIS and multi criteria model to evaluate different sites for selecting an appropriate area. The city of Sanandaj is growing fast and the residents need new infrastructures. Therefore the new sites recommended by the present study consider these prospects. This model can be applied to the other regions of the country which have almost similar natural and physical characteristics with the study area.

The authors would like to thank the anonymous referees for their helpful suggestions and comments. 


\section{References}

Al-jarreh, O., Abu-Qdis, H. 2004: Municipal Olidwaste landfill sitting using intelligent system. Waste Management journal 26. New York.

Chang, N. B., Parvathinathan, G., Breeden, J. B. 2008: Combining GIS with fuzzy multicriteria decision-making for landfill siting in a fast-growing urban region. Journal of Environmental Management 87-1. New York. doi: 10.1016/j.jenvman.2007.01.011

Chen, C. F. 2006: Applying the Analytical Hierarchy Process (AHP) Approach to Convention Site Selection. Journal of Travel Research 45-2. Virginia. doi: 10.1177/0047287506291593

Crouch, G., Ritchie, J. R. 2005: Application of the Analytic Hierarchy Process to Tourism Choice and Decision Making: A Review and Illustration Applied to Destination Competitiveness. Tourism Analysis 10. Elmsford.

EIO. 1997: A comprehensive study of environmental regulations of cemetery site selection in Iran. Environment Organization of Iran. Research and Education Board. Tehran.

Harker, P. T., Vargas, L. 1987: The Theory of Ratio Scaled Estimated: Saaty's Analytical Hierarchy Process. Management Science 33-11. Philadelphia. doi: 10.1287/mnsc.33.11.1383

Higges, G. 2006: Integrating multi-criteria techniques with Geographical Information Systems in waste facility location to enhance public participation. Journal of Waste Management \& Research 24. Stanford. doi: 10.1177/0734242X06063817

Ho, W. 2008: Integrated analytic hierarchy process and its applications - A literature review. European Journal of Operational Research. 186. New York.

Hojati, A. 2007: A review of urban land ownership and its impact on the urban development plans. Journal of economic sciences 22-2. Tehran.

Housing and Town Planning Center of Kurdistan Province 2000: A population report of Sanandaj City. Sannadaj.

Housing and Town Planning Center of Kurdistan Province 1976: Marjan Consulting Engineers. Mater Plan of Sananadaj. Sanandaj.

Khodadadi, F. 2003: The great cemetery of Royan. Monthly Journal of Municipality 43. Tehran.

Lee, W. B., Lau, H., Liu Z., Tam S. 2001: A fuzzy analytical hierarchy process approach in modular product design. Expert System 18-1. Oxford. doi: 10.1111/1468-0394.00153

Muralidhar, K., Santhanam, R., Wilson, R. L. 1990: Using the Analytic Hierarchy Process for Information System Project Selection. Information and Management 18. New York.

Partovi, F. Y. 2006: An analytic model for locating facilities strategically. The International Journal of Management science 34-1. New York. doi: 10.1016/j.omega.2004.07.018

Rashed, K., Weeks, J. 2003: Assessing vulnerability to earthquake hazards through spatial multi-criteria analysis of urban area. International Journal of Geographic Science 17-6. Abingdon.

Saaty, T. L. 1980: The Analytic Hierarchy Process. New York.

Saaty, T. L., Kearns, K. P. 1985: Analytical Planning: The Organization of Systems. Oxford.

Saeednia, A. 2002: Urban utilities and services. Municiple Green papers 8. Tehran.

SCI - Statistical center of Iran. 2007. Tehran.

Salvory, T., Bar, K., Bannet, B. T. 2005: Urban land use allocation in a Mediterranian ecotone: Habitat heterogeneity Model incorporated in a GIS using a multi-criteria mechanism. Journal of Landscape and Urban Planning 72. New York.

SOI Surveying Organization of Iran. 2004: Map series of Kurdistan Townships. Sheet 752BC. Tehran.

Sung, B., Kihan, S. D., Joo, H. 2005: Development of the feasibility model for adding new rail road station using AHP technique. Journal of Eastern Asia society for transportation Studies 6. Tokyo.

Vaidya, O. S., Kumar, S. 2006: Analytic hierarchy process: An overview of applications. European Journal of Operational Research 169-1. Amsterdam.

Zadeh, L. A. 1975: The concept of linguistic variable and its application to approximate reasoning. Information Sciences 8. New York. 


\title{
Povezovanje večkriterijskih modelov in GIS-ov za iskanje ustrezne lokacije za gradnjo pokopališča (študija primera: Sanandaj, Iran)
}

\author{
DOI: $10.3986 /$ AGS49106
}

UDK: 913:711.14(55)

711.14:718(55)

COBISS: 1.01

IZVLEČEK: Vedno večja rast mestnega prebivalstva vpliva na prostorsko načrtovanje v večini držav v razvoju. Tradicionalne metode prostorskega načrtovanja so še vedno uporabne, vendar jih je treba nadgraditi v skladu z novimi metodološkimi in tehnološkimi možnostmi in zapleteno naravo prostorskega načrtovanja. Na strukturo mesta in njegovo družbeno-gospodarsko podobo vplivajo številni dejavniki. Pri obdelavi tega ogromnega števila podatkov je $\mathrm{v}$ veliko pomoč geografski informacijski sistem (GIS), s katerim lahko uredimo in nadzorujemo posledice različnih problemov. Komunalni objekti predstavljajo ključni element pri zagotavljanju udobja prebivalcev. Neprimerna izbira lokacije za postavitev komunalne infrastrukture pogosto zmanjšuje učinkovitost mest in ovira njihov trajnostni razvoj. Kot visoko zmogljivo orodje za obdelavo podatkov danes GIS ponuja različne možnosti v prostorskem načrtovanju. Ena izmed najznačilnejših družbenih in verskih oblik mestne rabe zemljišč v Iranu so pokopališča, ki tradicionalno ležijo v bližini svetišč, njihovo lego pa lahko določijo tudi lokalne oblasti. Čeprav po mnenju ljudi in verskih skupin pokopališča ležijo na primernih mestih, vseeno povzročajo veliko težav, kot so na primer slabe zdravstvene razmere ter težja dostopnost zaradi velike rasti prebivalstva in posledičnega hitrega širjenja mest. $V$ članku poskušamo poiskati ustrezno mesto za novo pokopališče v mestu Sanandaj, ker je staro pokopališče zapolnjeno. Pri iskanju ustreznega območja uporabljamo GIS in metodo analitičnega hierarhičnega procesa (AHP). Izsledki kažejo, da lahko s pomočjo skupne obravnave z GIS in AHP primerjamo različne možnosti na podlagi preučevanja večkriterijskih modelov in različnih dejavnikov, ki sodelujejo v postopku izbire ustreznega mesta za postavitev komunalnega objekta.

KLJUČNE BESEDE: geografija, mestna raba zemljišč, večkriterijski model, izbira mesta za gradnjo pokopališča, GIS, Iran

Uredništvo je prejelo prispevek 2. februarja 2008.

NASLOV:

\section{dr. Sedigheh Lotfi}

Department of Urban Planning, University of Mazandaran

Pasdaran Street, 47415, P. O. Box: 416, Babolsar, Iran

E-mail: sedlotfi@yahoo.com

\section{dr. Kiumars Habibi}

Department of Urban Planning, University of Kurdistan, P. O. Box 416

Sanandaj, Iran

E-mail: habibi_ki@yahoo.co.uk

mag. Mohammad Javad Koohsari

Department of Urban and Regional Planning, Faculty of Fine Arts, University of Tehran

16 Azar Street, Enghelab Avenue, Tehran, Iran

E-mail: kouhsaary@yahoo.com

\section{Vsebina}

5 Literatura 198 


\section{Uvod}

Vedno večja stopnja urbanizacije povzroča mestnim oblastem in urbanistom veliko težav. Največji izziv današnjega časa je ustrezno razporediti komunalne objekte glede na različno rabo mestnih zemljišč in gostoto prebivalstva. $V$ večini držav v razvoju sprejemanje odločitev na tem področju ni več tako preprosto, kot je bilo pred širitvijo mest. Zelo pomemben napredek v urbanizmu predstavlja uporaba geografskega informacijskega sistema (GIS), ki je z visoko zmogljivostjo integriranja in analiziranja ogromnega števila podatkov pomembno orodje pri preučevanju značilnosti naselij. Zaradi gospodarskega razcveta leta 1970, ki ga je spodbudil povečan izvoz nafte, se je v Iranu spremenilo veliko mest, med njimi tudi Sanandaj. To mesto je eno izmed pomembnejših poselitvenih središč v zahodnem delu Irana, ki svojo sedanjo podobo dolguje glavnim in podrobnejšim urbanističnim načrtom. Glavni načrt mesta je bil izdelan zaradi povečane rasti prebivalstva in potreb po dodatni mestni infrastrukturi. Uveljavil je drugačno prostorsko zgradbo mesta in spremenil njegovo tradicionalno obliko, kar je povzročilo, da se je mesto fizično še bolj povečalo.

Selitev prebivalstva s podeželja v mesto je bila predvsem posledica upada kmetijske dejavnosti zaradi priliva prihodkov od izvoza nafte, kar pa je oslabilo podeželsko gospodarstvo. Poleg tega se je bil zaradi vdora iraških enot velik del prebivalstva na obmejnih območjih prisiljen umakniti v mesto. Število prebivalcev v mestu je tako s 95.000 leta 1976 naraslo na 205.000 v letu 1986 in na 315.000 leta 2006. Najočitnejša posledica teh dogodkov je bila izrazita rast mesta.

Raziskava temelji na dveh predpostavkah: 1. sedanje pokopališče ni primerno, saj povzroča veliko družbeno-gospodarskih in okoljskih težav; 2 izbira primernega mesta za tako rabo zemljišča je brez uporabe GIS-a težavna in draga, saj na postopek izbire ustrezne lokacije vpliva veliko kazalnikov in meril, ki jih je treba logično preučiti in pretehtati.

Izkazalo se je, da je zmogljivost GIS-a kot paketa programske in strojne opreme primerna za iskanje lokacij za komunalne objekte po celem svetu. Al-Jarreh in Abu-Qdais (2004) sta na primer obravnavala problem izbire lokacije za novo odlagališče odpadkov tako, da sta uporabila inteligentni programski sistem, ki je temeljil na teoriji mehkih množic oziroma na mehkem sklepanju (angleško fuzzy inference). Pri postopku izbire sta upoštevala več dejavnikov: relief in geološko sestavo, naravne vire, družbeno-kulturne vidike, ekonomičnost in varnost. Za vse dejavnike sta uporabila sistem določanja uteži. Rezultati preskušanja sistema na različnih lokacijah kažejo, da je sistem pri izbiranju učinkovit. Partovi (2006) je predstavil strateško rešitev za iskanje ustrezne lokacije za komunalni objekt, ki pri procesu odločanja vključuje zunanja in notranja merila in uporablja analitični hierarhični proces (AHP), analitični mrežni proces (angleško Analytical Network Process, ANP) in metodo razporeditve funkcije kakovosti (angleško Quality Function Deployment ali QFD). Chang in sodelavci (2007) so za iskanje primerne lokacije odlagališča odpadkov v južnem Teksasu uporabili večkriterijski mehki model odločanja v kombinaciji z GIS-om in postopek izpeljali v dveh fazah. Rashed (2003) je s prostorsko analizo mestnih predelov v Bangladešu ocenil potresno nevarnost, pri čemer je $z$ uporabo integriranega modela mehke logike in AHP določil območja z visokim, srednjim in nizkim tveganjem. Vastava in Nathawat (2002) sta izvedla raziskavo, s katero sta s pomočjo GIS-a in daljinskega zaznavanja pokazala, da je primerjava parov različnih kazalcev zelo uporabna za določanje ustreznega mesta za ureditev odlagališča v mestu Ranchi, ki ima 800 tisoč prebivalcev (Store in Kangs 2001). Z večkriterijsko metodo, ki vključuje niz različnih tehnik (vsoto uteži in analize pretvorbe), lahko ovrednotimo in utežimo določena merila, ki so odvisna od danega subjekta. Nato jih lahko strokovnjaki in urbanisti ustrezno razvrstijo (Higges 2006). Z večkriterijskimi metodami lahko zmanjšamo stroške in porabo časa, tako da povečamo natančnost pri prostorskih odločitvah, kar omogoča boljše načrtovanje rabe prostora. Eldin in Eldrandaly (2004) sta za iskanje primernega mesta za določeno vrsto komunalne infrastrukture uporabila nova sistema analitičnega hierarhičnega procesa in GIS. Salvory in sodelavci (2005) so v raziskavi, v kateri so povezali GIS in večkriterijske metode, preučevali ekološko ustreznost različnih tipov rabe zemljišč (npr. stanovanjskih in industrijskih območij, gozdov in zaščitenih območij). Za vsak tip rabe zemljišč so predlagali ustrezen podatkovni sloj in na koncu predlagali najprimernejšo rabo za vsak tip zemljišča. Sung in sodelavci (2005) so za iskanje ustrezne lokacije za gradnjo železniške postaje uporabili model AHP. Različna merila so utežili z uporabo mehke logike in analizo občutljivosti.

Danes je upravljanje s komunalno infrastrukturo v mestih vodilni izziv za mestne oblasti in urbaniste. Glavni cilj te raziskave je najti takšno mesto za novo pokopališče v mestu Sanandaj, ki bi imelo čim manj negativnih posledic za družbo in gospodarstvo ter okolje. Sanandaj je politično središče province Kurdistan, ki leži ob zahodni iranski meji. 


\section{Gradivo in metode}

Mesto Sanandaj, politično in gospodarsko središče province Kurdistan ob zahodni iranski meji, raste izredno hitro. Širjenje mesta pospešujeta razmeroma visok naravni prirastek prebivalstva in selitev s podeželja v mesto, zaradi česar je število prebivalstva s 95.000 leta 1976 naraslo na več kot 300.000 leta 2006 (SCI 2007). Najbolj izrazita posledica takšnega razvoja je močno širjenje mesta. Veliko komunalnih objektov in storitev v mestu ne more zadovoljiti rastočih potreb prebivalcev. Eden izmed teh objektov je tudi mestno pokopališče, ki je zapolnjeno. Glavni cilj te raziskave je z uporabo novih tehnik poiskati ustrezno mesto za novo pokopališče. Raziskava sledi vsebinski zasnovi, ki je predstavljena pod Sliko 1.

Slika 1: Vsebinska zasnova raziskave.

Glej angleški del prispevka.

GIS prednjači po zmožnosti integracije, modeliranja in iskanja ustreznih območij na podlagi ocenjevanja zemljišč. $S$ povezovanjem in izdelovanjem različnih meril lahko najdemo najustreznejše območje. Merila lahko izdelamo z uporabo različnih metod:

Boolova logika (angleško Boolean Logic): Metoda je svoje ime dobila po angleškem matematiku Georgu Boolu, ki je vsaki enoti v podatkovnem sloju določil osnovno vrednost »0« in »1«. Vsaka enota ima lahko dve vrednosti, »Da« ali »Ne«, pri čemer je vsako mesto ovrednoteno kot »pravilno« ali »napačno« (tretje možnosti ni). Na koncu model najde območje, ki je primerno ali neprimerno za opravljanje določene dejavnosti. Glavne pomanjkljivosti modela so: ne moremo ga uporabiti v resničnem svetu, ker so rezultati modela 100-odstotno pravilni ali napačni; če določeno merilo pri postopku iskanja območja postane neprimerno, se to območje opusti; četudi je meril veliko, model ne more samodejno najti ustreznega območja.

Prekrivanje podatkovnih slojev (angleško Index Overlay): pri tem modelu imajo različni dejavniki in razredi različne vrednosti, na podlagi katerih se izdela niz delnih zemljevidov z različnimi vrednostmi. Na primer, naklon površja razdelimo v naklonske razrede, ki so primerni za različne namene. $V$ našem primeru je za urbanistični razvoj primeren naklon med 2 in 5 stopinjami. Utežimo različne dejavnike, na primer pregibnice, smer naklona, količino prsti in podobno. Nazadnje z analizo spremenljivk združimo po dva podatkovna sloja in izberemo območje z višjo vrednostjo.

Verjetnostna logika: ta model s pomočjo modela koeficientov naključnosti, Cohenovega koeficienta kapa, entropije ter Moranovega in Cramerjevega indeksa povezuje različne podatkovne sloje in jih nato analizira na dveh ali več ravneh.

Korelacija koeficientov: analizirana bosta dva podatkovna sloja na podlagi razmerja med njima (npr. razmerja med višino in temperaturo, porazdelitvijo bolezni in gostoto prebivalstva itd.). Glavni cilj je ugotoviti stopnjo povezanosti in utežiti sloje glede na korelacijski koeficient.

Mehka logika ali logika neznanega in negotovosti: mehko logiko je sredi šestdesetih let prejšnjega stoletja razvil iransko-ameriški matematik Lotfi A. Zadeh, da bi oblikoval matematična pravila in funkcije za postavljanje vprašanj v »naravnem « jeziku. Mehka logika je orodje za računanje. Z njeno pomočjo so matematično predstavili številne koncepte, spremenljivke in sisteme, obenem pa je zagotovila tudi podlago za sklepanje, nadzor in odločanje v negotovih pogojih. Mehka množica za razliko od Boolovega modela omogoča konsistentno razvrščanje dejavnikov (Zadeh 1975).

Analitični hierarhični proces, ki ga je razvil Saaty (1980), je ena izmed pogosteje rabljenih večkriterijskih metod odločanja. Uporabljamo ga pri najrazličnejših oblikah odločanja in postopkih človekovega presojanja (Lee in ostali 2001). Z analitičnim hierarhičnim procesom lahko oblikujemo model vrednotenja, saj vsebuje merila za uteževanje. Različna merila povezuje v enoten rezultat, $s$ pomočjo katerega lahko razvrstimo različne možne odločitve. $Z$ njegovo uporabo ponavadi poenostavimo določen večkriterijski problem, saj ga razstavimo na več hiererhičnih slojev. Pri pridobivanju rešitev s pomočjo analitičnega hierarhičnega procesa ne gre za statistični proces, saj pomaga rešiti večkriterijske probleme tako posameznemu nosilcu odločanja kot tudi skupini, ki sprejema odločitve. Proces poteka v treh osnovnih korakih: razčlenitev oziroma oblikovanje hierarhije; primerjava oziroma določanje in zbiranje podatkov, na podlagi česar oblikujemo pare podatkov o posameznih elementih v hierarhični strukturi in jih med sabo primerjamo; sinteza oziroma oblikovanje splošne razvrstitve prednosti (Harker in Vargas 1987).

Nosilec odločanja mora zapletene večkriterijske probleme odločanja najprej razčleniti na njihove sestavne dele, pri čemer vse možne lastnosti teh sestavnih delov razporedi v več hierarhičnih slojev. 
Vsa merila niso enako pomembna za odločanje na vsaki stopnji hierarhije in so zato različno utežena. AHP omogoča izpeljavo analitičnega procesa, s katerim lahko združujemo ocene možnosti in merila po posamezniku ali skupini, ki sodeluje pri odločanju (Crouch in Ritchie 2005).

Sočasna primerjava dveh elementov znatno zmanjša vsebinsko zapletenost analize. Ta poenostavitev temelji na predpostavkah, ki se Sattyju (1980) in drugim (Muralidhar in ostali 1990; Partovi 1992) zdijo smiselne. Ker gre za primerjavo podatkovnih parov, analiza vključuje tri naloge: 1) oblikovanje primerjalne matrike na vsaki stopnji hierarhije, pri čemer začnemo na drugi stopnji in nadaljujemo po hierarhiji navzdol; 2) izračun relativnih uteži za vsak element hierarhije; in 3) oceno koeficienta skladnosti, na podlagi katerega lahko preverimo skladnost presojanja (Chen 2006). Primerjave lahko izpeljemo na podlagi osebnih ali subjektivnih presoj (Ho 2007).

$\mathrm{Na}$ devetstopenjski lestvici, ki se ponavadi uporablja pri analitičnih hierarhičnih raziskavah, si stopnje sledijo od 1 (ni razlike oziroma dejavnosti sta enako pomembni) do 9 (visoka prednost oziroma ena dejavnost je absolutno pomembnejša od druge; glej preglednico 1). S pomočjo te primerjave parov je nosilec odločanja lahko za vsak dejavnik posebej ocenil njegov prispevek k cilju, kar je poenostavilo postopek odločanja.

Preglednica 1: Devetstopenjska lestvica relativne pomembnosti (Satty in Kearns 1985).

\begin{tabular}{lll}
\hline raven pomembnosti & opredelitev & razlaga \\
\hline 1 & Enako pomembni dejavnosti. & $\begin{array}{l}\text { Dve dejavnosti enakovredno prispevata k danemu } \\
\text { cilju. }\end{array}$ \\
\hline 5 & Ena dejavnost je le rahlo pomembnejša od druge. & $\begin{array}{l}\text { Na podlagi izkušenj in presoje je ena dejavnost } \\
\text { rahlo pomembnejša od druge. }\end{array}$ \\
\hline 7 & Bistven ali močan pomen. & $\begin{array}{l}\text { Na podlagi izkušenj in presoje je ena dejavnost } \\
\text { močno pomembnejša od druge. }\end{array}$ \\
\hline 9 & Dokazan pomen. & $\begin{array}{l}\text { Ena dejavnost je izrazito pomembnejša, kar je } \\
\text { dokazano tudi v praksi. }\end{array}$ \\
\hline $2,4,6,8$ & $\begin{array}{l}\text { Dokazi potrjujejo, da je ena dejavnost absolutno } \\
\text { pomembnejša od druge. }\end{array}$ \\
\hline
\end{tabular}

Na vsaki stopnji se elementi primerjajo po parih glede na vpliv, ki ga imajo na element na naslednji višji stopnji. Če začnemo na vrhu hierarhije in nadaljujemo navzdol, lahko parne primerjave na določeni stopnji zreduciramo na število kvadratnih matrik $A=\left[\alpha_{i j}\right]_{n x n}$, kot to lahko vidimo v naslednjem primeru:

$$
\left(\begin{array}{cccc}
a_{11} & a_{12} & \ldots & a_{1 n} \\
a_{21} & a_{22} & \ldots & a_{2 n} \\
\cdot & \cdot & & \cdot \\
a_{1 n} & a_{2 n} & \ldots & a_{n n}
\end{array}\right)
$$

Matrika ima recipročne lastnosti:

$$
a_{j i}=\frac{1}{a_{i j}}
$$

Po oblikovanju matrik vseh primerjav parov se vektor uteži $w=\left[w_{1}, w_{2}, \ldots, w_{n}\right]$ izračuna s pomočjo Sattyjevega postopka za izračun lastnega vektorja. Izračun uteži poteka v dveh korakih. Najprej matriko primerjave parov $A=\left[\alpha_{i j}\right]_{n \times n}$ normaliziramo z enačbo (1), nato pa $\mathrm{z}$ enačbo (2) izračunamo uteži.

$$
a_{i j}{ }^{*}=\frac{a_{i j}}{\sum_{i=1}^{n} a_{i j}}
$$

za vsak $j=1,2, \ldots, n$ 


$$
w_{i}=\frac{\sum_{j=1}^{n} a_{i j}^{*}}{n}
$$

za vsak $i=1,2, \ldots, n$

Satty (1980) je dokazal povezavo med vektorskimi utežmi $w$ in parno primerjalno matriko $A$, ki je izražena z naslednjo enačbo:

$$
A w=\lambda_{\max } w
$$

Vrednost $\lambda_{\max }$ je pomemben kontrolni parameter $\mathrm{v}$ analitičnem hierarhičnem procesu. Uporablja se kot referenčni indeks za prikaz podatkov prek izračuna koeficienta skladnosti (KS; angleško consistency index) določenega vektorja. Za izračun KS lahko indeks skladnosti (IS) za vsako matriko v velikostnem razredu $n$ izračunamo iz naslednje enačbe:

$$
C I=\frac{\lambda_{\max }-n}{n-1}
$$

Nato lahko izračunamo KS s pomočjo naslednje enačbe:

$$
C R=\frac{C I}{R I}
$$

pri čemer je IN indeks naključne skladnosti, ki ga izračunamo s pomočjo naključno izdelane matrike primerjave parov. Tabela 2 prikazuje vrednosti $I N$, izračunane na podlagi matrik v velikostnem razredu od 1 do 10 , kot je to predlagal Satty (1980). Če je $K S<0,1$, so primerjave sprejemljive, če pa je $K S \geq 0,1$, vrednosti koeficienta kažejo na nesprejemljivost izbire. $V$ tem primeru je treba prvotne vrednosti v primerjalni matriki A preveriti in ustrezno popraviti.

Preglednica 2: Indeksi naključne neskladnosti (in) za n =1-10 (Satty 1980).

\begin{tabular}{ccccccccccc}
\hline 10 & 9 & 8 & 7 & 6 & 5 & 4 & 3 & 2 & 1 & $\mathrm{~N}$ \\
\hline 1,49 & 1,46 & 1,41 & 1,32 & 1,24 & 1,12 & 0,9 & 0,58 & 0,00 & 0,00 & $\mathrm{Rl}$ \\
\hline
\end{tabular}

Analitični hierarhični proces se uporablja v šolstvu, gradbeništvu, upravi, industriji, gospodarskem upravljanju, proizvodnji, politiki, družbi, športu pa tudi pri osebnem odločanju (Vaidya in Kumar 2006). Metoda je uporabna na toliko različnih področjih, ker ni zapletena, je preprosta za uporabo in izredno prilagodljiva. Uporablja se lahko skupaj z drugimi tehnikami (na primer matematičnim programiranjem); na ta način omogoča upoštevanje tako kvalitativnih in kvantitativnih dejavnikov kot tudi realnih omejitev.

\section{Predstavitev in uporaba modela}

Pri iskanju ustreznega mesta za gradnjo pokopališča so pomembni številni prostorski in fizičnogeografski dejavniki, saj običajno določajo meje pokopališča in njegove fizičnogeografske lastnosti (Khodadadi 2003). Mednje spadajo:

- Oddaljenost od mesta: po muslimanskem izročilu pokopališče od mesta ne sme biti oddaljeno več kot $15 \mathrm{~km}$, saj bi drugače verniki lahko zamudili čas molitve ali prekinili post (Saeednia 2002). Poleg tega je pri določanju oddaljenosti od mesta treba upoštevati sanitarne vidike.

- Fizično širjenje mesta: pokopališče mora stati na mestu, za katerega je najmanj verjetno, da se bo tja mesto širilo.

- Prostor ob pokopališču: izbrano mesto mora imeti na razpolago dovolj zemljišč, poraslih z drevesi, ali golih zemljišč, ki pokopališče primerno ločijo od drugih mestnih predelov.

- Prevladujoča smer vetra: veter mora pihati proti pokopališču. V nasprotnem primeru mora biti pokopališče obdano $\mathrm{z}$ visokimi drevesi. 
- Dostopnost: po muslimanskem verovanju je petek najsvetejši dan v tednu in verniki na ta dan radi obiščejo pokopališče in se poklonijo svojim pokojnim sorodnikom. Zato je pomembno, da so ceste, ki vodijo do pokopališča, varne in ustrezno urejene.

- Vrsta in sestava prsti: Vrsta prsti in njena sestava ne smeta povzročiti, da se trupla umrlih razkrajajo dlje od pričakovanega.

- Trdnost tal: podlaga mora biti odporna proti plazenju (zemeljskim plazovom) in padanju (skalnim podorom).

- Naklon: mesto mora imeti tak naklon, ki omogoča dobro in hitro odtekanje meteornih voda.

- Raven podtalnice: V skladu s 40. in 45. členom ustreznega predpisa Iranske organizacije za okolje mora biti raven podtalnice vsaj pet metrov pod grobovi. Ta organizacija je v Iranu izvedla temeljito raziskavo okoljskih predpisov, povezanih z iskanjem ustreznih mest za gradnjo pokopališč (EOI 1997).

- Površinske vode: pokopališče ne sme stati v bližini rek, izvirov ali podzemnih vodovodnih kanalov - qanatov.

Model smo izpeljali v dveh fazah. Najprej smo z uporabo prekrivanja podatkovnih slojev v GIS-u določili lokacije glede na njihovo prostorsko primernost. Utežili smo različne dejavnike in izdelali več delnih zemljevidov. Nato smo ocenili naslednja merila glede na njihovo pomembnost: prevladujoča smer vetra: območja, ki so ležala v nasprotni smeri vetra, smo utežili kot najprimernejša; smer fizičnega širjenja mesta: najboljše lokacije so bile tiste, ki ležijo v nasprotni smeri širitve mesta; oddaljenost od mesta: lokacije, ki so od upravne meje mesta oddaljene vsaj $3 \mathrm{~km}$ (in največ $15 \mathrm{~km}$ ), smo ocenili kot najprimernejše za gradnjo pokopališča; bližina površinskih voda: območja, ki so bolj oddaljena od vodnih virov (npr. rek), smo ocenili kot primernejša za gradnjo pokopališča; in dejavnik dostopnosti: izbrano mesto mora imeti dober dostop do glavnega prometnega omrežja. Vsa zgornja merila smo ustrezno razvrstili in utežili. Na primer, dejavnik oddaljenosti smo utežili, kot prikazujejo preglednice od 3 do 7 .

Preglednica 3: Obtežitev prevladujoče smeri vetrov.

\begin{tabular}{ll}
\hline prevladujoča smer vetrov & utež \\
\hline območja v smeri prevladujočih vetrov & 0,00 \\
ostala območja & 1,00 \\
\hline
\end{tabular}

Preglednica 4: Obtežitev smeri širjenja mesta.

\begin{tabular}{ll}
\hline smer širjenja mesta & utež \\
\hline območja v smeri širjenja mesta & 0,00 \\
ostala območja & 1,00 \\
\hline
\end{tabular}

Preglednica 5: Obtežitev oddaljenosti od mesta.

\begin{tabular}{ll}
\hline oddaljenost od mesta $(\mathrm{v} \mathrm{km})$ & utež \\
\hline $0-3$ & 0,00 \\
$3-6$ & 0,50 \\
$6-9$ & 1,00 \\
$9-12$ & 0,75 \\
$12-15$ & 0,25 \\
$<15$ & 0,00 \\
\hline
\end{tabular}

Preglednica 6: Obtežitev oddaljenosti od površinskih voda.

\begin{tabular}{ll}
\hline oddaljenost od površinskih voda $(\mathrm{km})$ & utež \\
\hline $0-1$ & 0,00 \\
$1-3$ & 0,25 \\
$3-5$ & 0,50 \\
$5-7$ & 0,75 \\
$<7$ & 1,00 \\
\hline
\end{tabular}


Preglednica 7: Obtežitev faktorja dostopnosti.

\begin{tabular}{lc}
\hline distance from the main roads $(\mathrm{km})$ & weight \\
\hline 2,0 & 0,00 \\
$1,5-2,0$ & 0,25 \\
$1,0-1,5$ & 0,50 \\
$0,5-1,0$ & 0,75 \\
$0,0-0,5$ & 1,00 \\
\hline
\end{tabular}

Utežene sloje smo v GIS-u povezali s pomočjo prekrivanja podatkovnih slojev, nato pa smo na podlagi lokacijskih meril prikazali primernost lokacij (Slika 2). Osnovni zemljevid, ki smo ga uporabljali, je bil digitalizirani zemljevid mestne občine Sanandaj, ki ga je leta 2004 izdala Iranska geodetska organizacija (SOI, 2004).

Slika 2: Povezovanje različnih meril z metodo prekrivanja podatkovnih slojev.

Glej angleški del prispevka.

V drugi fazi smo z uporabo modela analitičnega hierarhičnega procesa za izbor najprimernejšega območja glede na prostorske dejavnike izbrali najpomembnejši merili: vrsta prsti (prepustnejše prsti so primernejše za gradnjo pokopališča, ker se lahko trupla pokojnih v njih bolje razgradijo) in naklon (območje mora imeti tak naklon, ki omogoča hitro odtekanje meteornih voda). Ti dve merili smo skupaj z drugimi lokacijskimi dejavniki, ki smo jih utežili v prvi fazi, analizirali s pomočjo analitičnega hierarhičnega procesa.

V analitičnem hierarhičnem procesu smo uporabili primerjalno matriko zgornjih meril (glej preglednico 4). Primerjavo parov smo izpeljali na podlagi več sestankov s krajevnimi urbanisti in občinskimi strokovnjaki. Merila smo večkrat pregledali in jih tako uskladili s krajevnimi razmerami. Na koncu so mestne oblasti potrdile naslednje rezultate.

Preglednica 4: Matrika primerjave parov v modelu AHP.

\begin{tabular}{lccc}
\hline merila & lokacijski dejavniki & vrsta prsti & naklon \\
\hline dejavniki & 1,00 & 2,00 & 3,00 \\
vrsta prsti & 0,50 & 1,00 & 2,00 \\
naklon & 0,33 & 0,50 & 1,00 \\
\hline
\end{tabular}

Koeficient neskladnosti pri primerjavi je znašal 0,0045, kar je bilo sprejemljivo, saj mora biti njegova vrednost manjša ali enaka 0,1 . Pri tej raziskavi smo za izračun relativne pomembnosti dejavnikov in kazalnikov uporabili profesionalno programsko opremo (glej preglednico 5).

Programska oprema Expert Choice temelji na analitičnem hierarhičnem procesu. Uporabnik mora najprej opredeliti problem in hierarhično vnesti vse relevantne podatke. Nato elemente paroma primerja glede na njihov pomen in jih nazadnje razvrsti v homogene skupine. Uporabnik mora navesti, za koliko je X pomembnejši od $\mathrm{Y}$, program pa nato z besedilnim ali grafičnim hierarhičnim analitičnim procesom določi vrednosti od 1 do 9. Program tudi pomaga ugotoviti, ali so izbrana razmerja logična in dosledna ter tako pomaga uporabniku, da izboljša rezultat. Program nazadnje združi vse primerjave parov in izračuna relativen pomen posameznih dejavnikov.

Preglednica 5: Uteževanje meril v modelu analitičnega hierarhičnega procesa.

\begin{tabular}{ll}
\hline merila & utež \\
\hline dejavniki & 0,48 \\
vrsta prsti & 0,27 \\
naklon & 0,16 \\
\hline
\end{tabular}


Podatkovne sloje za vsako merilo smo dobili s pomočjo GIS-a. Sloje smo nato razvrstili v razrede in vsakemu razredu določili prednosti v zvezi z gradnjo pokopališča. Potem smo te sloje utežili glede na AHP s pomočjo dodatka v programu ArcGIS9.

Med različnimi možnimi območji sta dve območji imeli večjo težo glede na izbrane dejavnike. Seveda ima vsak model svoje pomanjkljivosti in lahko opravi le omejeno analizo okolja, ki je sicer izjemno kompleksno, zato je treba rezultate uporabljati le kot vodilo in skupaj z drugimi orodji (npr. terenskimi raziskavami). V naši raziskavi smo uporabljali digitalni zemljevid vrste prsti in zemljevid naklona za mesto Sanandaj, ki ga je izdala Iranska geodetska organizacija (2004).

Da bi bil projekt tudi dejansko izvedljiv, smo preverili lastništvo na teh dveh območjih. Na tem mestu je treba omeniti, da je netransparentnost na področju lastništva mestnih zemljišč eden najpomembnejših dejavnikov, ki onemogočajo izvedbo urbanističnih projektov v Iranu (Hojati 2007); izkušnje kažejo, da marsikateri urbanistični načrt ni upošteval pomena tega vprašanja, kar je pripeljalo do tega, da se je na občinskih policah nakopičilo veliko neuporabnih osnutkov. V naši raziskavi pa smo pri vrednotenju priporočenih območij upoštevali ceno zemljišč in njihovo lastništvo (glej sliko 3). To olajša delo nosilcem odločanja, krajevne oblasti pa lahko načrte tudi izpeljejo.

Slika 3: Povezovanje različnih meril s pomočjo modela AHP.

Glej angleški del prispevka.

\section{Izsledki in razprava}

Na izbor komunalnih objektov, kot je pokopališče, vpliva veliko dejavnikov, z uporabo tradicionalnih metod pa je nemogoče analizirati tako veliko število podatkov. Uporaba tradicionalnih metod je povzročila veliko težav v državnem urbanističnem načrtovanju in močno obremenila naravne vire z zmogljivimi analitičnimi orodji, kot je GIS, lahko močno olajšamo načrtovanje in zmanjšamo probleme. Kljub temu moramo upoštevati, da je tudi GIS zgolj orodje. Njegovi uporabniki so tisti, ki izberejo podatke za vnos in jih nato ocenjujejo; če so vneseni podatki nepravilni, so lahko rezultati zelo zavajajoči.

$\mathrm{V}$ prostorskem načrtovanju je uporaba večkriterijskih modelov, kot je analitični hierarhični proces, skupaj z GIS-om učinkovita in omogoča primerjavo različnih možnosti, kar nam pomaga izbrati najboljšo rešitev.

Priporočeni model se lahko uporablja tudi v drugih delih države, ki imajo enake naravne razmere, ali pa se lahko prilagodi za uporabo na izbranem območju tako, da se mu dodajo druga merila, osnovne lastnosti modela pa se ne spreminjajo.

Mnenja urbanistov bomo upoštevali in vključili njihove želje in premisleke v znanstven in ciljno usmerjeni pristop. Nobenega načrta pa ne moremo udejanjiti brez pomoči krajevne uprave. Prepričani smo, da lahko za vse ustvarimo ugodnejši položaj, v kolikor o prednostih modela obveščamo vse organe, ki sodelujejo v prostorskem načrtovanju in upravljanju mest. Rezultati raziskave sedanjega in predlaganega novega pokopališča so naslednji:

- Podatki o smeri vetra v zadnjih petih letih kažejo, da vetrovi večinoma pihajo iz južne pokrajine ob reki Gheshlaq proti mestu. Zato naj bi predlagano pokopališče ležalo v nasprotni smeri vetra;

- Oddaljenost od površinskih voda je na nekaterih območjih manjša od $100 \mathrm{~m}$. Sedanje pokopališče leži $500 \mathrm{~m}$ stran od reke in desetine vodnjakov, ki predstavljajo glavni namakalni vir tukajšnjim kmetijskim površinam. Povprečna raven podtalnice v sosednjih provincah Ilam, Zanjan in Kermanshah je na globinah 114 (Ilam), 108 (Zanjan) in $127 \mathrm{~m}$ (Kermanshah). Raven podtalnice pa se na tem območju lahko zmanjša tudi na $25 \mathrm{~m}$. Običajna povprečna globina podtalnice v državi je $68,9 \mathrm{~m}$, zato predstavlja onesnaženje podtalnice za mesto velik problem. Predlagano območje za gradnjo novega pokopališča ima ustrezen naklon, ki omogoča naravno odtekanje onesnažene vode, prav tako pa je dovolj oddaljeno od površinskih voda;

- Naklon območja sedanjega pokopališča je povečini več kot $22^{\circ}$ (standardni naklon je pod $22^{\circ}$ ). Povprečni naklon novega območja pa je manj kot $14-17^{\circ}$.

- Podatki kažejo, da se mesto Sanandaj širi proti jugu in jugovzhodu (več kot $90 \%$ rasti). Sedanje pokopališče leži na območju mestnih storitvenih dejavnosti. V raziskavi sta bili predlagani dve najprimernejši območji, kot je to prikazano v Sliki 3. 
- Med letoma 1996 in 2006 je povprečna stopnja umrljivosti znašala 8 umrlih na 1000 prebivalcev. Tako letno umre 2200 ljudi. Pri vsakem pokopu je potrebnih $6 \mathrm{~m}^{2}$ zemlje, kar letno znese $13.200 \mathrm{~m}^{2}$ ali 1,3 ha zemlje. Zaradi ekonomičnosti naj bi novo območje zadostovalo za vsaj 30 let, torej bi se moralo raztezati na 40 ha zemljišč. Sedanja lokacija ima namreč omejeno možnost širjenja, zadostuje pa samo še za približno devet let.

- Izsledki raziskave so pomembni za lokalno skupnost in nosilce odločanja, saj je uporabljeni model prilagojen družbeno-gospodarskim in naravnim značilnostim regije. Metodo smo namreč lokalizirali in izbrali dve najprimernejši novi območji. Omeniti je treba, da je bilo na področju izbora primernih območij v državi narejenih že več raziskav, ker pa se je večina osredotočala zgolj na omejeno število dejavnikov, mestne oblasti njihovih rezultatov niso nikoli izvedle v praksi. To raziskavo končujemo z naslednjimi zaključki: raziskava je pokazala, da je v bližnji prihodnosti nujno treba izbrati novo mesto za gradnjo pokopališča. Zato smo $\mathrm{z}$ uporabo GIS-a in večkriterijskega modela poskušali preučiti različne družbeno-gospodarske in fizičnogeografske dejavnike in tako z ocenjevanjem različnih lokacij izbrati primerno območje. Mesto Sanandaj izredno hitro raste in njegovi prebivalci potrebujejo dodatno infrastrukturo. Pri lokacijah, predlaganih v tej raziskavi, so bili zato upoštevani vsi ti vidiki. Model se lahko uporablja tudi $\mathrm{v}$ drugih pokrajinah $\mathrm{v}$ državi, ki imajo podobne naravne in fizičnogeografske značilnosti kot obravnavano območje.

Avtorji bi se radi zahvalili anonimnima ocenjevalcema za njune dragocene predloge in komentarje.

\section{Literatura}

Glej angleški del prispevka. 